\title{
Effect of Planting Patterns and Nk Fertilizers Levels under Two Planting Date on Yield and Fiber Properties of Egyptian cotton In Middle Egypt
}

Ghoprial M. A. S. *, S. A. Sedhom**, M A. A. Emara*, E. M. M. El-Gedwy** and S. A. S. Mehasen ${ }^{1 * *}$

* Cotton Research Institute, Agricultural Research Center, Giza, Egypt

**Agronomy Department, Faculty of Agriculture, Benha University, Egypt

${ }^{1}$ Corresponding author: Sadiek Abdelaziz Sadiek Mehasen, Head Department of Agronomy, Faculty of Agriculture at Moshtohor, Benha University, Egypt. PO Box 13736.

\begin{abstract}
Two separate field experiments were conducted during 2019 and 2020 seasons, at Mallawi region, Minia Governorate, Egypt, to study the effect of two planting date, four planting patterns and three NK fertilizer levels on yield and fiber properties of Egyptian cotton (Gossypium barbadense, L.) promising hybrid cotton (CB58 X Giza 90). The results could be summarized as follows was observed: Planting date significantly affect seed cotton yield fed $^{-1}$ and lint index in the both seasons and micronaire reading, $2.5 \%$ span length and length uniformity ratio in the first season only. Regarding planting patterns significant effect on seed cotton yield fed ${ }^{-1}$ and lint index in the both season. NK fertilizer levels had a significant effect on seed cotton yield fed ${ }^{-1}$ and lint index in both seasons and fiber strength and $2.5 \%$ span length in the first season only. Seed cotton yield fed ${ }^{-1}$ was affected by the interaction between planting date and planting patterns in the first season. It can be concluded that early planting, $130 \mathrm{~cm}$ bed width and $30 \mathrm{~cm}$ hill space planted in two sides and fertilized by $75 \mathrm{~kg} \mathrm{~N}+48 \mathrm{~kg} \mathrm{~K}_{2} \mathrm{O}_{\text {fed }}^{-}$ ${ }^{1}$ under the conditions in middle Egypt.
\end{abstract}

Key Words: Planting dates, Planting patterns, NK fertilizer levels, Fiber properties, Egyptian cotton

\section{Introduction}

Egyptian cotton (Gossypium barbadense, L.) is the most important commercial fiber crop in Egypt. Cotton plays a key role in the economy. It is the oldest among the commercial crops and is known as white gold. Egyptian cotton is preferred around the world because it is a long fiber that makes it softer and stronger at the same time. For many years, it was so valuable that most of the crop was exported to European countries. Cotton seed meal is used in food products for animal feed due to its high protein and energetic values. So, it is necessary to increase cotton cultivation area and productivity. Cotton is not only the most important fiber crop of the world but also the second best source for plant proteins after soybean and the oil ranking fifth in the world use among edible oils (Sawan et al, 2006). Economic characters are influenced by the various agronomic treatments especially planting date, planting patterns and the amount of fertilizers.

In this connection, planting dates differ in affect cotton yield and fiber properties as reported by Elhamamsey et al (2016), Khan et al (2017), Emara et al (2018b), Anwar, et al (2020).

Planting patterns is one of the management practices which require attention as far as optimum yield is concerned in cotton production. The suitable plant population $\mathrm{fed}^{-1}$ resulting in higher yield and earlier maturity. Such findings are in harmony with those obtained by Wang et al (2016), Kumar et al (2017), Ghoprial et al (2018), Anwar, et al (2020).

Consequently, many workers reported that NK fertilizer levels are the most limiting factor to increase cotton yield and fiber properties by Dewdar and
Rady (2013), Ghoprial et al (2018), Zakzok et al (2018), Deshish (2021b).

This study aimed to investigate the suitable agricultural management practices such as planting dates and patterns and NK fertilizer levels of new promising hybrid cotton (CB58X Giza 90).

\section{Materials and Methods}

Two field experiments were carried out in Mallawi region, Minia Governorate, during 2019 and 2020 seasons to study the effect of two planting date $\left(20^{\text {th }}\right.$ March and $20^{\text {th }}$ April), four planting patterns $\{65$ $\mathrm{cm}$ ridges width $+25 \mathrm{~cm}$ hills space $\left(\mathbf{P}_{1}\right), 65 \mathrm{~cm}$ ridges width $+30 \mathrm{~cm}$ hill space $\left(\mathbf{P}_{2}\right), 130 \mathrm{~cm}$ bed width +25 $\mathrm{cm}$ hill space planted in two sides $\left(\mathbf{P}_{\mathbf{3}}\right), 130 \mathrm{~cm}$ bed width $+30 \mathrm{~cm}$ hill space planted in two sides $\left.\left(\mathbf{P}_{4}\right)\right\}$ and three NK fertilizer levels $\left\{45 \mathrm{~N}+24 \mathrm{~K}_{2} \mathrm{O} \mathrm{kg} \mathrm{fed}{ }^{-1}\right.$ $\left(\mathbf{N K}_{1}\right), 60 \mathrm{~N}+36 \mathrm{~K}_{2} \mathrm{O} \mathrm{kg} \mathrm{fed}{ }^{-1}\left(\mathbf{N K}_{2}\right), 75 \mathrm{~N}+48 \mathrm{~K}_{2} \mathrm{O}$ $\left.\mathrm{kg} \mathrm{fed}{ }^{-1}\left(\mathbf{N K}_{3}\right)\right\}$ on yield and fiber properties of Egyptian cotton (Gossypium barbadense, L.) promising hybrid cotton (CB58 X Giza 90). The soil was clay in texture with a $\mathrm{pH}$ value of 8.14 and 8.23 , an organic matter content of 1.99 and $2.05 \%$, available $\mathrm{N}$ of 0.112 and $0.125 \%$ and available $\mathrm{K}$ of 0.330 and $0.335 \%$ during the first and second seasons, respectively. It should be noted that the preceding crop was corn in the two seasons. Data in Table 1 showed the measured climatic factors (maximum air temperature ${ }^{\circ} \mathbf{C}$ (Max. Temp.), minimum air temperature ${ }^{\circ} \mathbf{C}$ (Min. Temp.), Average relative humidity \% (Avg. RH) and Soil Temp. ${ }^{\circ} \mathrm{C}$ (Min. Temp.) during the experimental period (March till October during 2019 and 2020 seasons). These data 
collected from automated weather station of Mallawi location.

The variables in each experiment were distributed as randomized complete block design (RCBD) using split split-plot arrangement with 4 replicates. Two sowing dates were arranged in the main plots, the sub plots were assigned random by to the four planting patterns randomly and the three NK fertilizers levels were arranged random by in the sub sub-plots. The area of each sub sub-plot was $23.4 \mathrm{~m}^{2}$ (including 6 ridges width of ridge was $65 \mathrm{~cm}$ and the length of ridge was $6 \mathrm{~m}$ ).

Table 1. Average monthly climatic data of Mallawi location during the two studied seasons of $2019 \& 2020$.

\begin{tabular}{ccccc}
\hline Month & Max. Temp. ${ }^{\circ} \mathrm{C}$ & Min. Temp. ${ }^{\circ} \mathrm{C}$ & Ave. RH $\%$ & Soil Temp. ${ }^{\circ} \mathrm{C}$ \\
\hline March & 46.2 & First season (2019) & \\
April & 36.7 & 19.0 & 50.8 & 37.9 \\
May & 46.1 & 18.8 & 57.4 & 31.6 \\
June & 46.3 & 15.9 & 38.5 & 35.9 \\
July & 45.9 & 19.1 & 39.2 & 37.2 \\
August & 46.2 & 19.5 & 46.2 & 38.3 \\
September & 42.6 & 19.0 & 50.0 & 39.2 \\
October & 33.7 & 17.1 & 47.9 & 38.5 \\
\hline March & & 18.2 & 47.4 & 38.7 \\
April & 47.1 & Second season (2020) & 28.8 \\
May & 36.9 & 20.1 & 49.2 & 32.0 \\
June & 44.9 & 19.4 & 58.2 & 36.4 \\
July & 46.8 & $16 . .9$ & 39.3 & 38.3 \\
August & 44.7 & 19.5 & 37.9 & 38.3 \\
September & 47.7 & 20.0 & 45.6 & 39.4 \\
October & 44 & 19.7 & 49.1 & 39.1 \\
\hline
\end{tabular}

Phosphorus fertilizer was added at a level of 22.5 $\mathrm{kg}$ after ridging and before planting in both seasons. Each season contained two separate experiments represented the two planting dates, i.e. $20^{\text {th }}$ March and $20^{\text {th }}$ April. Nitrogen fertilizer in the form of ammonium nitrate $(33.5 \% \mathrm{~N})$ at the tested levels was applied before the second and third irrigations in two equal doses, Potassium fertilizers in the form of potassium sulfate $\left(48 \% \mathrm{~K}_{2} \mathrm{O}\right)$ at the tested levels was applied before third irrigation in one doses. Other agricultural practices were done as recommended in region.

At harvest, seed cotton yield (kentar fed $\left.{ }^{-1}\right)$ was estimated as the weight of seed cotton yield $(\mathrm{kg})$ picked from the whole plot in each experimental unit collected from two picks, then converted to yield fed ${ }^{-}$ ${ }^{1}$ in $\operatorname{kentar}(1 \mathrm{Kentar}=157.5 \mathrm{~kg}$ seed cotton $)$.

Samples of lint were collected from each treatment at each replicate to determine the following characters at the laboratories of Cotton Research Institute, ARC, under standard conditions of test by using High Volume Instrument (HVI) according to (A.S.T.M., 1986), for the following traits: micronaire reading, fiber strength (g/tex), $2.5 \%$ span length $(\mathrm{mm})$, length uniformity ratio $(\%)$, lint index. Data collected on different parameters were analyzed statistically by using MSTAT-C programme (Anonymous, 1986) for analysis of variance. Whenever, the results were found to be significant, the treatments means were compared using LSD at 0.05 level of probability (Steel et al., 1997).

\section{Results and Discussion}

\section{-Effect of planting dates:}

Planting date was significantly effect of seed cotton yield $\mathrm{fed}^{-1}$ and lint index in the both seasons and micronaire reading, $2.5 \%$ span length and length uniformity ratio in the first season only as shown Table 2. Planting date at $20^{\text {th }}$ March was significantly increase of seed cotton yield fed ${ }^{-1}$ and lint index in the both seasons and $2.5 \%$ span length and length uniformity ratio in the first season only. Whereas, planting date at $20^{\text {th }}$ April were significantly increase of micronaire reading in the second season only, Fiber strength is no significant effect in the two seasons. This may be attributed to the high genetic stability of these characters. The present results are in general accordance with those obtained by Said (2011), Awan et al (2011), Elayan et al (2015), Emara et al (2018b) and Anwar et al (2020). 
Table 2. Yield and fiber properties of Egyptian cotton as affected by planting date in 2019 and 2020 seasons

\begin{tabular}{|c|c|c|c|c|c|c|}
\hline \multirow[b]{2}{*}{ Characters } & \multicolumn{2}{|c|}{2019 season } & \multirow{2}{*}{$\begin{array}{c}\text { LSD } \\
\text { at } \\
5 \%\end{array}$} & \multicolumn{2}{|c|}{2020 season } & \multirow{2}{*}{$\begin{array}{c}\text { LSD } \\
\text { at } \\
\mathbf{5 \%}\end{array}$} \\
\hline & $\begin{array}{c}\text { 20 }^{\text {th }} \\
\text { March }\end{array}$ & $\begin{array}{c}\text { 20 }^{\text {th }} \\
\text { April }\end{array}$ & & $\begin{array}{c}20^{\text {th }} \\
\text { March }\end{array}$ & $\begin{array}{c}20^{\text {th }} \\
\text { April }\end{array}$ & \\
\hline Seed cotton yield fed ${ }^{-1}$ (kentar) & 11.74 & 8.10 & 0.23 & 8.12 & 6.76 & 0.73 \\
\hline Micronaire reading & 5.07 & 5.18 & 0.10 & 4.97 & 5.08 & NS \\
\hline Fiber strength (g/tex) & 9.37 & 9.31 & NS & 9.45 & 9.43 & NS \\
\hline $2.5 \%$ span length $(\mathrm{mm})$ & 31.58 & 30.93 & 0.11 & 31.81 & 31.63 & NS \\
\hline Length uniformity ratio (\%) & 83.85 & 82.99 & 0.34 & 84.09 & 83.93 & NS \\
\hline Lint index $(\mathrm{g})$ & 6.67 & 6.08 & 0.12 & 7.24 & 6.63 & 0.29 \\
\hline
\end{tabular}

NS=No significance

\section{-Effect of planting patterns:}

Data in Table 3 showed that seed cotton yield fed ${ }^{-}$ ${ }^{1}$ and lint index were significantly affected by planting patterns in two seasons. The highest values of seed cotton yield fed $^{-1}$ (10.16 and 7.94 kentar) and lint index $(6.71$ and $7.29 \mathrm{~g})$ in the first and second seasons, respectively obtained by $\mathrm{P} 4$ treatment. On the other hand, the micronaire reading, fiber strength, $2.5 \%$ span length and length uniformity ratio were no significant in the two seasons. This results are in harmony with those obtained by. Awan et al (2011), Hamoda et al (2013), Hamoda and Emara (2014), Başal, et al (2014), Kumar et al (2017), Ghoprial et al (2018) and Deshish (2021b).

Table 3. Yield and fiber properties of Egyptian cotton as affected by planting patterns in 2019 and 2020 seasons

\begin{tabular}{|c|c|c|c|c|c|}
\hline \multirow[b]{2}{*}{ Characters } & \multicolumn{4}{|c|}{2019 season } & \multirow{2}{*}{$\begin{array}{c}\text { L.S.D at } \\
\mathbf{5 \%}\end{array}$} \\
\hline & $\mathbf{P}_{1}$ & $\mathbf{P}_{2}$ & $\mathbf{P}_{3}$ & $\mathbf{P}_{4}$ & \\
\hline Seed cotton yield fed ${ }^{-1}$ (kentar) & 9.70 & 10.15 & 9.68 & 10.16 & 0.22 \\
\hline Micronaire reading & 5.08 & 5.06 & 5.09 & 5.13 & NS \\
\hline Fiber strength (g/tex) & 9.34 & 9.31 & 9.30 & 9.36 & NS \\
\hline $2.5 \%$ span length $(\mathrm{mm})$ & 30.93 & 31.29 & 31.24 & 31.56 & NS \\
\hline Length uniformity ratio (\%) & 83.44 & 83.75 & 83.20 & 83.29 & NS \\
\hline \multirow[t]{2}{*}{ Lint index (g) } & 6.08 & 6.42 & 6.27 & 6.71 & 0.16 \\
\hline & \multicolumn{4}{|c|}{2020 season } & \\
\hline Seed cotton yield fed-1 (kentar) & 7.10 & 7.56 & 7.18 & 7.94 & 0.28 \\
\hline Micronaire reading & 5.02 & 4.99 & 5.01 & 5.08 & NS \\
\hline Fiber strength (g/tex) & 9.41 & 9.44 & 9.43 & 9.48 & NS \\
\hline $2.5 \%$ span length $(\mathrm{mm})$ & 31.77 & 31.54 & 31.59 & 31.99 & NS \\
\hline Length uniformity ratio (\%) & 83.88 & 84.25 & 83.90 & 84.01 & $\mathrm{NS}$ \\
\hline Lint index $(\mathrm{g})$ & 6.65 & 7.03 & 6.78 & 7.29 & 0.09 \\
\hline
\end{tabular}

$\mathbf{P}_{1}=65 \mathrm{~cm}$ ridges width $+25 \mathrm{~cm}$ hills space

$\mathbf{P}_{3}=130 \mathrm{~cm}$ bed width $+25 \mathrm{~cm}$ hill space planted in two sides

$P_{2}=65 \mathrm{~cm}$ ridges width $+30 \mathrm{~cm}$ hill space $\mathrm{NS}=$ No significance

\section{-Effect of NK fertilizer levels:}

The results obtained in Table 4 reveal that NK fertilizer levels had a significant effect on seed cotton yield fed ${ }^{-1}$ and lint index in both seasons, fiber strength and $2.5 \%$ span length in the first season only. $\mathrm{NK}_{3}$ treatment gave the highest values of seed cotton yield fed $^{-1}$ (10.21 and 7.71 kentar), fiber strength (9.49 and $9.46 \mathrm{~g} /$ tex), $2.5 \%$ span length (31.83 and 31.92 $\mathrm{mm})$ and lint index (6.56 and $7.18 \mathrm{~g})$ in the first and second seasons, respectively. These results may be due to the well-known roles of $\mathrm{N}$ in building up the plant tissues and stimulating their growth. It is well established that the cotton plant, owing to its indeterminate growth habit, responds favorably to increasing NK levels, and its growth is linearly correlated with $\mathrm{N}$ supply. Similar results were obtained by Ghoprial et al (2018), Zakzok et al (2018), Emara et al (2020), Deshish (2021a) and Deshish (2021b).

\section{- Interactions Effect:}

The interactions effects between the experiment factors were not significant on the all studies traits in both seasons except seed cotton yield fed $^{-1}$ was affected by the interaction between planting date and planting patterns in the first season (Table 5). Sown in $20^{\text {th }}$ March under $\mathrm{P}_{2}$ treatment gave the highest value of seed cotton yield fed $^{-1}$ (12.19 kentar) in the first season. On the other hand, the lowest value of seed cotton yield fed $^{-1}$ (7.80 kentar) were obtained by sown in $20^{\text {th }}$ April under $\mathrm{P}_{1}$ treatment in the first season. 
Table 4. Yield and fiber properties of Egyptian cotton as affected by NK fertilizer levels in 2019 and 2020 seasons

\begin{tabular}{|c|c|c|c|c|c|c|c|c|}
\hline \multirow[b]{2}{*}{ Characters } & \multicolumn{3}{|c|}{2019 season } & \multirow{2}{*}{$\begin{array}{c}\text { LSD } \\
\text { at } \\
\mathbf{5 \%}\end{array}$} & \multicolumn{3}{|c|}{2020 season } & \multirow{2}{*}{$\begin{array}{c}\text { LSD } \\
\text { at } \\
5 \% \\
\end{array}$} \\
\hline & $\mathbf{N K}_{1}$ & $\mathrm{NK}_{2}$ & $\mathrm{NK}_{3}$ & & $\mathbf{N K}_{1}$ & $\mathrm{NK}_{2}$ & $\mathbf{N K}_{3}$ & \\
\hline Seed cotton yield fed f $^{-1}$ (kentar) & 9.58 & 9.97 & 10.21 & 0.30 & 7.12 & 7.49 & 7.71 & 0.30 \\
\hline Micronaire reading & 5.04 & 5.07 & 5.16 & NS & 5.03 & 5.02 & 5.01 & NS \\
\hline Fiber strength (g/tex) & 9.24 & 9.29 & 9.49 & 0.09 & 9.44 & 9.41 & 9.46 & NS \\
\hline $2.5 \%$ span length (mm) & 30.97 & 30.96 & 31.83 & 0.23 & 31.58 & 31.67 & 31.92 & NS \\
\hline Length uniformity ratio (\%) & 83.25 & 83.46 & 83.55 & NS & 83.74 & 84.09 & 84.20 & NS \\
\hline Lint index $(\mathrm{g})$ & 6.17 & 6.38 & 6.56 & 0.15 & 6.63 & 7.01 & 7.18 & 0.17 \\
\hline
\end{tabular}

Table 5. Effect of the interaction between of planting date and patterns on seed cotton yield fed ${ }^{-1}$ (kentar) in 2019 and 2020 seasons

\begin{tabular}{|c|c|c|c|c|c|c|c|c|}
\hline \multirow{3}{*}{ Planting date } & \multicolumn{4}{|c|}{2019 season } & \multicolumn{4}{|c|}{2020 season } \\
\hline & \multicolumn{8}{|c|}{$\begin{array}{l}\text { Seed cotton yield fed } \text { f }^{-1}(\text { kentar}) \\
\end{array}$} \\
\hline & $\mathrm{P}_{1}$ & $\mathrm{P}_{2}$ & $\mathrm{P}_{3}$ & $\mathrm{P}_{4}$ & $\mathrm{P}_{1}$ & $\mathrm{P}_{2}$ & $\mathrm{P}_{3}$ & $\mathrm{P}_{4}$ \\
\hline $20^{\text {th }}$ March & 11.60 & 12.19 & 11.48 & 11.69 & 7.84 & 8.22 & 7.83 & 8.60 \\
\hline $20^{\text {th }}$ April & 7.80 & 8.10 & 7.88 & 8.63 & 6.35 & 6.89 & 6.52 & 7.27 \\
\hline L.S.D at $5 \%$ & \multicolumn{4}{|c|}{0.31} & \multicolumn{4}{|c|}{ NS } \\
\hline
\end{tabular}

$\mathbf{P}_{1}=65 \mathrm{~cm}$ ridges width $+25 \mathrm{~cm}$ hills space $\quad \mathbf{P}_{2}=65 \mathrm{~cm}$ ridges width $+30 \mathrm{~cm}$ hill space $\quad$ NS=No

significance

$\mathbf{P}_{3}=130 \mathrm{~cm}$ bed width $+25 \mathrm{~cm}$ hill space planted in two sides sides

\section{References}

Anwar M. R., B. Wang, D. L. Liu and C. Waters, 2020. Late planting has great potential to mitigate the effects of future climate change on Australian rain-fed cotton. Sci. of the Total Environment 714 (136806):1-13.

Awan H., I. Awan, M. Mansoor, E. A. Khan and M. A. Khan, 2011. Effect of sowing time and plant spacing on fiber quality and seed cotton yield. Sarhad J. Agric., 27(3): 411-413.

Deshish El-D. El-D., 2021a. Effect of row width and spacing between hills on growth, yield and quality of cotton variety Giza 96 under different levels of NPK fertilization. J. Plant Production, Mansoura Univ., 12 (3):225-230.

Deshish El-D. El-D., 2021b. Effect of plants distribution systems on growth, yield and quality of cotton variety Giza 96 under different levels of NPK fertilization. J. Plant Production, Mansoura Univ. 12 (3):243-248.

Dewdar M. D. H. and M. M. Rady, 2013. Influence of soil and foliar applications of potassium fertilization on growth, yield and fiber quality traits in two Gossypium barbadense L. Afr. J. Agric. Res., 8(19): 2211-2215.

Elhamamsey, M. H., E. M. Shalaby, E. A. Ali and M. A. Emara, 2016. Effect of some cultural practices on shedding and yield of Egyptian cotton. Assiut J. Agric. Sci., 47 (4):41-51.

Emara M. A. A., S. A. F. Hamoda and Maha M.A. Hamada, 2018. Effect of potassium silicate and NPK fertilization levels on cotton growth and
$\mathbf{P}_{4}=130 \mathrm{~cm}$ bed width $+30 \mathrm{~cm}$ hill space planted in two productivity under different sowing dates. Egy. J. Agron. The 15 th Int. Conf. Crop Sci., pp. 115-123.

Ghoprial M. A., S. A. Sedhom, S. A. S. Mohasen, and F. S. Hamed, and El-Saeed M. M. ElGedwy, 2018. Effect of population density and nitrogen fertilizer levels on growth, yield components, yield, and fiber properties of Egyptian cotton (Giza 95). Annals of Agric. Sci., Moshtohor, 56 (1):1-13.

Hamed F. S., 2012. Response of Giza 90 cotton cultivar to sowing dates and first irrigation (almohayat) time. J. Plant Production, Mansoura Univ., 3 (12): 3027-3035.

Khan A., L. Wang, S. Ali, S. A. Tung, A. Hafeez and G. Yang, 2017. Optimal planting density and sowing date can improve cotton yield by maintaining reproductive organ biomass and enhancing potassium uptake. Field Crops Research (214): 164-174.

Kumar P.; A. S. Karle. D. Singh and L. Verma, 2017. Effect of high-density planting system (hdps) and varieties on yield, economics and quality of desi cotton. Int. J. Curr. Microbiol. App. Sci. 6(3): 233-238.

Wang, X., Y. Hou, M. Du, D. Xu, H. Lu, X. Tian, and $\mathrm{Z}$. Li, 2016. Effect of planting date and plant density on cotton traits as relating to mechanical harvesting in the Yellow River valley region of China. Field Crops Res., 198: 112-121.

Zakzok A. K., R. Th. Abdrabou, A. S. Arafa and G. A. A. Abd-Elsamad, 2018. Response of cotton yield and lint properties to mineral N.P.K nanofertilization. J. Agric. Sci., 26 (2): 1029 -1039. 
تأثير نظم الزراعة ومستويات التسميد النيتروجيني والبوتاسي تحت ميعادي زراعه علي المحصول وصفات التيلة للقطن

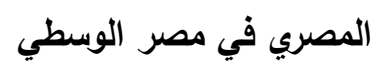

ميلاد عاطف شاكر غبريال" ، سيدهم أسعد سيدهم" ، مصطفي عطية أحمد عمارة" ، السعيد محمد محمود الجدوي" " وصديق عبد العزيز صديق محيسن"

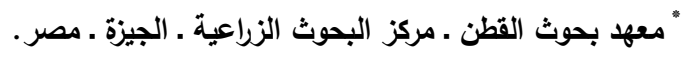

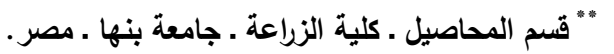

أجريث هذه الدراسة بمنطقه ملوي - محافظة المنبا خلال موسمي الزراعة 2019 و2020 لدراسة ثأثير أربعة نظم الزراعة وثلاث

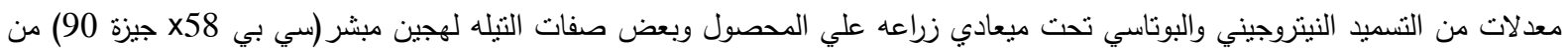

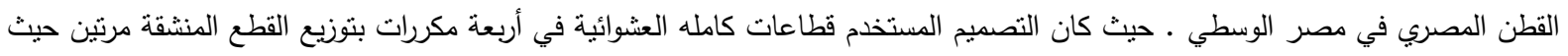

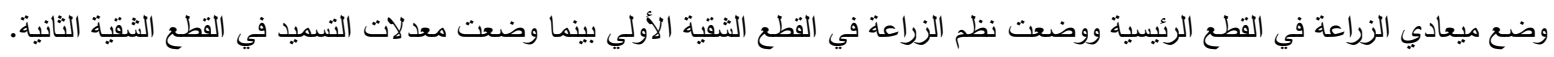

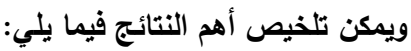

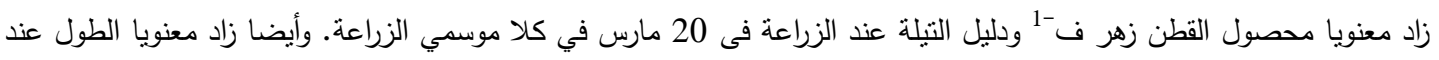

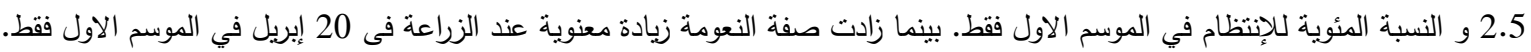

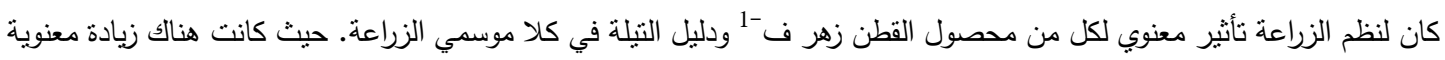

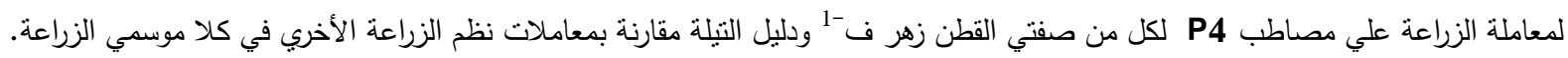

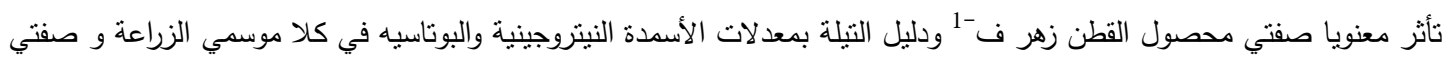

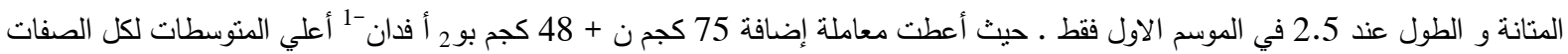

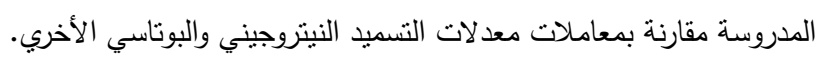

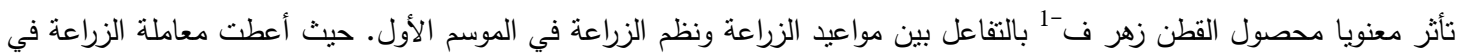

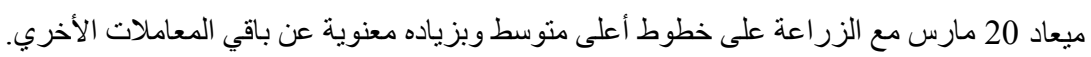
توصي هذه الدراسة بالزر اعة في ميعاد 20 مارس و الزر اعة علي مصاطب مع التسميد بمعدل 75كجم نيتروجين+48كجم بوتاسيوم ف-1. 